\title{
Vocabulary Acquisition Through Expository Texts
}

\author{
Anita Fatimatul Laeli \\ University of Muhammadiyah Jember \\ (anita@unmuhjember.ac.id)
}

\begin{abstract}
This paper is based on a study on students' vocabulary acquisition after reading in the same topic. The aim of this study is to find out the effect of applying Narrow Reading on the students' vocabulary acquisition. The data were the students' vocabulary test results which were analyzed to see the progress after five - times treatment. The results reveal that the students' vocabulary acquisition increased as shown by the improvement of on word knowledge in term of spelling, word meaning, part of speech and word production.
\end{abstract}

Keywords: narrow reading, vocabulary acquisition, incidental learning

Acquisition refers to gradual development of ability which involves reasoning, perception, memory, and storage in a language by using it naturally in communicative situations (Johnson, 2001, pp. 76-77). Based on this definition, it can be said that vocabulary acquisition is the deepest process of acquiring, which involves reasoning, perception, memory and storage of words. In this present study, vocabulary acquisition is gained while reading and it is in the form of the score of the vocabulary test that covers spelling, part of speech, word meaning and word production.

In vocabulary acquisition, memorizing some new words and their meaning without being related to the context will not retain for a long period of time, the words will be easily forgotten. In addition Krashen (2009, p. 11) states that true vocabulary acquisition with long term retention occurs only with meaningful exposures in situation in which real communication takes place. Therefore in order to restore the words into long term memory they should be connected to the context.

Long Term Memory represents information that is stored for considerable period of times (Westwood, 2007, p. 44). Long term-memory has an enormous capacity, and its contents are durable over time. Further, Westwood (2007, p. 44) state psychologists usually distinguish between different types of long-term stored information; episodic memory, semantic memory, or procedural memory. Episodic memory refers to the memories that someone has for times, events and places. Procedural memory refers to the ability to recall the steps in a particular process, skill or strategy. Semantic memory refers to the memories of meaningful facts, rules, definitions, concepts, and principles. In term of memorizing the vocabulary, it is involved in semantic memory.

Concerning with long term memory, in this present study, students are expected to memorize vocabulary permanently. In order to ensure material moves into permanent longterm memory, Thornbury (2002,p. 24) summarize some of the research findings that can help the learners memorize vocabulary permanently, they are through Repetition, Retrieval, Spacing. The focus of this study is providing repetition of word that is occurred in narrow reading.

The idea of narrow reading is behind the theory of input hypothesis offered by 
Krashen (1985, cited in Kimura \& Ssali, 2009, p. 9). Krashen's input hypothesis claims language is acquired when learners are exposed to a large amount of comprehensible input, at or just beyond their present level of language knowledge and skills. Krashen (1985) argues that comprehensible input is easy to be provided through narrow reading because common vocabulary and discourse is often repeated within a single topics or similar contexts. For this reason, the input hypothesis is believed to be closely related to narrow reading.

\section{Narrow Reading}

Based that theory, Krashen (2004, p. 17) define narrow reading as reading on the same topic over the course of a number of texts or reading several books by one author which help the reader's to ensure comprehension and meet natural repetition of vocabulary and grammar. Similarly, Zhao (2007, p. 1) argues that Narrow reading, originally defined as a learning strategy, in which the learner read the books written by one author, or about a single topic of interest, or in one genre. In addition, Schmitt and Carter (2000, p. 6) define narrow reading as reading numerous texts but all on the same topic. For example, someone follow a continuing story in a newspaper or reading magazine on a particular topic of interest.

From those definitions, it can be concluded that narrow reading is a strategy in reading where the reader focus only reading several texts in the same topic or reading several stories book written by one author. Simply saying, narrow reading means reading in only one genre, one subject matter, or the work of one author.

Concerning with the case vocabulary acquisition through narrow reading, a previous study was done by Gardner (2008). This study focuses on the investigation on the collections of authentic texts with common theme, or written by one author. The collections of the text are distinguished by the relative theme tightness and authorship and register (narrative and expository). Then, those texts were analyzed to determine how often, and under what conditions, specialized vocabulary recycles within the materials. The finding indicated that thematic relationship impacted specialized vocabulary recycling within expository collections (especially content word), whereas, authorship impacted specialized vocabulary recycling within narrative collection (especially names of character, place, etc.).

Therefore, in term of text register, narrow reading can be divided into two types that are, narrative (reading a story by one author) and expository (reading several articles or books in the same topic). Relating to those types of narrow reading, this present study will provide the reader with expository text which means the subject of this study will read several texts but in one topic.

Commonly, most foreign and second language classes present the students with exposure to a variety of topics. Typically the students read from one topic to another topic for example, the students read a text about "shopping" then the next meeting, they read about "sport", etc. In other cases, in a certain subject sometimes students are only given one short example of some different authors' work. Only later, in higher courses, a second language learner concentrate on particular subject, for example by taking classes in analyzing single author's work, focusing in reading particular topic, etc. Krashen (2004, p. 16) argues that it would be much better if second language learners concentrate on one field early rather than late. Further, Krashen (2004) argues that narrow input is much more efficient for second language acquisition. In conclusion, the early application of reading several books by one author or about a single topic of interest is a good idea.

The case for narrow reading is based on the idea that the acquisition of both structure and vocabulary comes from many exposures in a comprehensible context, that is, students acquire new structures and words when understanding the messages. According to Krashen $(2004$, p. 17) states that narrow 
reading facilitates this process in several ways. First, since each writer has favorite expressions and a distinctive style, and each topic has its own vocabulary and discourse, narrow reading provides built- in review. Second, background of knowledge is a tremendous facilitator of comprehension. Narrow readers gain more contextual knowledge as they read narrowly: The more one reads in one area, the more one learns about the area, and the easier one finds subsequent reading in the area (and the more one acquires of the language). It can be concluded that comprehensible input generates better input. In relation to the idea, offered by Krashen (2004), that each topic has its own vocabulary, Thornbury $(2002$, p. 53) states that lexical fields (words that have thematic relationship) are easier to be learned than lexical sets.

Further, Schmitt and Carter (2000) state that reading in one subject means that much of the topic-specific vocabulary will be repeated throughout the course of reading, which both makes the reading easier and gives the reader a better chance of learning this recurring vocabulary.

In brief, narrow reading has the advantage of providing the reader with a familiar context, that is, familiar background knowledge that make texts more comprehensible. Narrow reading also has the advantage of repeated exposure to the same vocabulary.

For those reason, The topic that is selected in this study is "Education" specifically the theme that will be selected in is "Teaching Vocabulary", it is hoped that the output from reading one topic will help the students to have a better input concerning with education, since the subject of this study is the university students in English education major.

\section{Incidental Learning}

In second language teaching and learning, there are two types of vocabulary learning: incidental learning and intentional learning. Hatch and Brown (1995, p. 368) defined intentional learning as learning that is being designed planed for or intended by teacher. Incidental learning, on the other hand, is the type of learning that is by product of doing or learning something else. In terms of vocabulary learning, incidental learning means the approach of learning vocabulary through texts, working on tasks or doing other activities that are not directly related to vocabulary. This means that the learner does not intend to acquire the vocabulary, this process usually through reading comprehension. This process of acquiring vocabulary is done implicitly as the aim of the activity to read the passage. The side effect emerging from this activity will be advantages for learners. In this way, the new vocabulary comes as natural result of this process.

According to Huckin and Coady (1999) as cited in Hsien-jin (2001, p. 31), incidental learning happens during extensive reading when learners try to guess the meaning of unknown words from context and automatically acquire the new words. This is supported by an experiment showing that approximately 16 percent of all unknown words are acquired just in one reading (Yun, 1989 in Hatch and Brown 1995, p. 369). Since the vocabulary acquisition mostly through reading comprehension, the efforts to familiarize reading skill are required. The incidental learning of words from reading comprehension, still according to Hatch and Brown (1995, p. 369), is apparently powerful in foreign language rather than in second language.

Furthermore, the process of incidental learning has certain advantages, for example the process of vocabulary learning in contextual within the reading. It enables two activities, reading and vocabulary learning, to occur at the same time. Not all the words are easy to remember, according to Hatch and Brown (1995, p. 380) it is easier to understand and remember content words which are beginning from the easiest, noun, adjective, verb and adverb. Noun is easier than verb, as learner and form mental images of them more rapidly. While functional words such as preposition, articles, conjunctions, forms indicating number, gender or tense and pronouns are more difficult to learn. Therefore, it can be said 
that only vocabulary with high frequency use that will be remembered by learners. Learners will remember easily words which are related with the environment.

Deliberate learning of vocabulary is very important for encountering a word at the first time. However, it is only the incidental learning or the repeated encounter with the word in a meaningful context that helps consolidate the learning in the learners' mind. Meeting a word repeatedly through reading helps the readers know how the words can be used in different contexts, and the multiple meaning of the words.

Based on the idea for the beneficial strategy of narrow reading, this study is aimed to investigate the effectiveness of applying narrow reading in helping the students acquire vocabulary. The students in this study are university students in English Education major at $3^{\text {rd }}$ semester.

\section{Method}

This study is quasi-experimental design with pretest-posttest design. Since it is quite difficult to randomize the subjects to the intended conditions as it is committed in true experimental design. The subjects in this study are unsystematically selected into experiments group and control group. According to Ary, et al (2002, p. 303) experimental group (E) is the group that is given the independent variable (the treatment is narrow reading), while control group (C) is the group that does not receive the experimental treatment, it receives a different treatment (broad reading).

The procedures of the design are as follows: The students in $3^{\text {rd }}$ semester are selected as the subject of this study. Finally two classes out of four classes are chosen as the subject of this study. The total number of the selected students of the two classes is about 25 students in which they are divided into experimental and control group. The two selected classes then assigned into control group and experimental group randomly. The amount of the subject for each group is about
25 students. Before the implementation of the treatment, the control and the experiment class were given pre test. The scores of pretest, then, are analyzed to ensure the homogeneity of the two classes. It is done to know that the students in both of the group have the same ability. The activities of reading in narrow topic (expository texts) as the treatment is given to the experimental group only while control group is given another treatment; wide reading (reading in many topics). The posttest was given to both of the two groups after treatment. The final scores of the test were analyzed using ANCOVA, with posttest score of both groups as the dependent variable and reading scores as the covariate to control other possible variable (Ary, et al., 2002, p. 293).

\section{Instruments}

The reading materials used in the present study consisted of five passages. Those passages were separate texts which related through the topic. Each text has different title but has the same topic of discussion. The selected topic for this study is education, specifically on the issue of "Teaching Vocabulary". The following is the list of the texts used in this study.

These reading materials were selected by the researcher based on the need in this research. These texts were from electronic resources (internet). The length of those texts is at least two pages and consists of $1000-1500$ words. The reading materials were taken from the collections of articles provided by the $\mathrm{BBC}$ online forum.

The target words that were tested after reading the materials were content word with high frequency to be repeated in all the passages. In order to account for the role of frequency, target words are grouped according to the number of times they appeared in the text, constituting four different frequency groups: 1- 2 occurrence, $3-4$ occurrence, $6-9$, and 10 or more.

The form of test in this study was vocabulary test. The vocabulary test consisted of spelling test, part of speech, and word meaning and word production. Spelling test was used to 
Table 1. List of the text

\begin{tabular}{ccl}
\hline No & \multicolumn{1}{c}{ Theme } & \multicolumn{1}{c}{ Title } \\
\hline 1. & Teaching Vocabulary & Multi-word Verb: learners problem \\
\hline 2. & Teaching Vocabulary & Multi-word Verb: Methods \& Approach \\
\hline 3. & Teaching Vocabulary & Presenting vocabulary \\
\hline 4. & Teaching Vocabulary & 7 steps to vocabulary learning \\
\hline 5. & Teaching Vocabulary & Working with Vocabulary \\
\hline
\end{tabular}

measure students' word knowledge in term of word spelling. Part of speech test was used to measure students' word knowledge in term of word class. Meaning word recognition test was used to measure students' word knowledge in term of word meaning. The second type of the test was given both pretest- posttest for both of the group; control and experimental group after the first test.

\section{Data Analysis}

In this research the data were analyzed by using a statistic technique. The scores of the post test of both the control group and the experimental group were analyzed by using ANCOVA formula in SPSS 16 for Windows. By the following description; the scores of posttest of two groups (experiment and control group) is used as the dependent variable in which the students' reading score in previous Reading class as the control variable (covariate). It was done to know whether there are significant difference scores of experiment and control group in the vocabulary test after the implementation of narrow reading.

\section{Result and Discussion}

The data was analyzed using ANCOVA through SPSS 16.0 program for windows. Analysis of Covariance (ANCOVA) is a statistical technique that is used to control for the effect of an extraneous variable known to be correlated with the dependent variable (Ary. et al., 2002, p. 292). The objective of ANCOVA is to determine the effect of treatment on response variables by controlling other variables. In other words relate to this study, ANCOVA analysis is used to determine whether there is an influence of the students' reading competence in the form of reading score (covariate) on the students' vocabulary acquisition (response variable), and it is also used to determine the effect of different treatments (narrow reading and broad reading) on the student' vocabulary acquisition.

Before ANCOVA analysis is done, firstly the researcher has tested the data normality and the data homogeneity. In experimental research, the data normality and data homogeneity are very important steps to be done before testing of the hypothesis is processed. The Kolgomorov-Sminorv analysis is used to determine the normality of the data. Thus, the normality test is done on Vocabulary test from the control class and experiment class.

The table shows that the value of Asymp. Sig. (2-tailed); pretest experiment is 0.764 , posttest experiment is 0.753 , pretest control is 0.946 and posttest control is 0.930 ; is more than 0.05 , therefore it can be said that the data distribution is normal (Wijaya, 2009, p. 126).

Next, the data is also calculated using Lavene test to know the homogeneity of the data. The result of the Lavene test can be seen in detail in this following table.

Table 4.2 shows that F- Levene test of vocabulary test is 1.548 with the probability of 0.220 . Since the $\mathrm{p}$-Level value is bigger than 0.05 , it can be concluded that the data is homogeny. In other word, the variance between the control class and experimental class for 
vocabulary test is not different (homogeny). In brief, it can be said that this data is equal variances assumed.

Specifically, this study was done to know whether there is a significant difference in scores between experiment and control group in vocabulary test (posttest) after exposed to narrow reading. With the following description, the dependent variable is vocabulary acquisition (in form of students' score in vocabulary test) and the independent variable is narrow reading. However, in fact

Table 2. One Sample Kolmogorov-Smirnov Test

\begin{tabular}{|c|c|c|c|c|c|}
\hline & & $\begin{array}{c}\text { Pretest } \\
\text { Experimental } \\
\end{array}$ & $\begin{array}{c}\text { Posttest } \\
\text { Experimental }\end{array}$ & $\begin{array}{l}\text { Pretest } \\
\text { Control }\end{array}$ & $\begin{array}{l}\text { Posttest } \\
\text { Control }\end{array}$ \\
\hline $\mathrm{N}$ & & 25 & 25 & 25 & 25 \\
\hline \multirow[t]{2}{*}{ Normal Parameters ${ }^{\mathrm{a}, \mathrm{b}}$} & Mean & 48.12 & 67.16 & 48.44 & 51.48 \\
\hline & $\begin{array}{l}\text { Std. Devia- } \\
\text { tion }\end{array}$ & 8.604 & 8.557 & 6.889 & 6.084 \\
\hline Most Extreme & Absolute & .134 & .135 & .105 & .109 \\
\hline \multirow[t]{2}{*}{ Differences } & Positive & .134 & .135 & .105 & .091 \\
\hline & Negative & -.088 & -.062 & -.063 & -.109 \\
\hline $\begin{array}{l}\text { Kolmogorov- } \\
\text { SmirnovZ }\end{array}$ & & .668 & .674 & .524 & .543 \\
\hline Asymp. SIg. (2-tailed) & & .764 & .753 & .946 & .930 \\
\hline
\end{tabular}

a. Test distribution is Normal.

b. Calculated from data.

Table 3. F-Lavene's Test

\begin{tabular}{|c|c|c|c|}
\hline & & \multicolumn{2}{|c|}{ Vocabulary test } \\
\hline & & $\begin{array}{c}\text { Pretest } \\
\text { Experimental } \\
\end{array}$ & $\begin{array}{c}\text { Posttest } \\
\text { Experimental }\end{array}$ \\
\hline Levene's Test for & $\mathrm{F}$ & 1.548 & \\
\hline Equality of Variances & Sig. & .220 & \\
\hline t-test for Equality of & $\mathrm{t}$ & 7.467 & 7.467 \\
\hline \multirow[t]{6}{*}{ Means } & $\mathrm{df}$ & 48 & 43.324 \\
\hline & Sig. (2-tailed) & .000 & .000 \\
\hline & Mean Difference & 15.680 & 15.680 \\
\hline & Std. Error Difference & 2.100 & 2.100 \\
\hline & $\begin{array}{l}\text { 95\% Confidence Interval Lower } \\
\text { of the Difference }\end{array}$ & 11.458 & 11.446 \\
\hline & Upper & 19.902 & 19.914 \\
\hline
\end{tabular}


Table 4. ANCOVA Analysis

Dependent variable: Posttest_score

\begin{tabular}{lrrrrr}
\hline \multicolumn{1}{c}{ Source } & $\begin{array}{c}\text { Type III Sum } \\
\text { of Squares }\end{array}$ & df & Mean Square & F & \multicolumn{1}{c}{ Sig. } \\
\hline Corrected Model & $3440.783^{\text {a }}$ & 2 & 1720.392 & 35.494 & .000 \\
\hline Intercept & 1812.254 & 1 & 1812.254 & 37.389 & .000 \\
\hline Nilai_Reading & 367.503 & 1 & 367.503 & 7.582 & .008 \\
\hline Experimental_Control & 2845.192 & 1 & 2845.192 & 58.700 & .000 \\
\hline Error & 2278.097 & 47 & 48.470 & & \\
\hline Total & 181662.000 & 50 & & & \\
\hline Corrected Total & 5718.880 & 49 & & & \\
\hline
\end{tabular}

a. R Squared $=.602($ Adjusted R Squared $=.585)$

there are other factors that also affect the students' vocabulary acquisition through narrow reading, one of which is the students' reading competence. Therefore, the students' reading competence (in the form of the students' reading score that was taken from previous result in reading subject) is used as a control variable (covariate) to reduce the error rate.

The input data for ANCOVA analysis is from the result of posttest from both of the groups and the students' reading score as the covariate. The result of the analysis can be seen from the output of SPSS in table 4.3.

From the output above, it can be seen that the significance value for variable reading score is 0.008 . Because the sig. $<0.05$ then $\mathrm{H} 0$ is rejected. This means that on the $95 \%$ confidence level can be said there is an influence of the students' reading competence in the form of reading score (covariate) on the students' vocabulary acquisition (response variable). This statement indicates that the assumption of ANCOVA was met.

Further to know the effect of narrow reading on students' vocabulary acquisition, it can be done by ignoring the "Reading Score" effect from the model. From the table output above, it can be seen that the significance value for experiment and control (in which only experiment group received narrow reading) is
0.000 . Since the significance value is far from being 0.05 , so $\mathrm{H} 0$ is rejected. Consequently, it can be concluded that without the effect of reading ability variable, on the $95 \%$ confidence level can be said that the posttest scores between experiment and control groups were significantly different.

Above all, to know whether reading score and the application of narrow reading affect the student's vocabulary acquisition, simultaneously can be seen from the significant value of corrected model. From the output, the significance value of corrected model is 0.000 . Since the significance value is far from 0.05 so $\mathrm{HO}$ is rejected. In brief, on the $95 \%$ confidence level can be said that reading competence and narrow reading have a significant influence on the students' vocabulary acquisition (in the form of vocabulary test' score).

Thus, it can be concluded that is there is a significant difference between score of experiment and control class in vocabulary test (posttest) after exposed to narrow reading.

\section{Result and Discussion}

The results of the study indicate that narrow reading can be used as a means to acquire new words. In brief, narrow reading 
has the advantage of providing the reader with a familiar context, that is, familiar background of knowledge that make texts more comprehensible. Moreover the topic of Narrow Reading used in this study is teaching vocabulary, it is very appropriate with the students background knowledge since the subject of this study is students of University in English Education Faculty. Further, Narrow reading also has the advantage of repeated exposure to the same vocabulary for a certain topic. This aspect also makes students more easily to remember some word related with the topic.

Thus, a theory; by Schmitt and Carter (2000) state that reading in one subject means that much of the topic-specific vocabulary will be repeated throughout the course of reading, which both makes the reading easier and gives the reader a better chance of learning this recurring vocabulary; is accepted. The examples in this study are like the word item, context, phrasal, etc. Those words are repeated 6-10 occurrence in all the texts given, and those words are also related to the topic that has been selected in this study (teaching vocabulary). In the result of the text, $\pm 80 \%$ of students pass the vocabulary test relating to those words. It is in accordance with, Nation (1990 cited in Schmitt, 2005, p. 831) states that words are required 5-16 or more repetitions to be learned.

Further, the assumption; that the word would be easier to master, if the word has high repetition in a reading text is able to be proven in this study. In which logically the reader would also met the word many times while they are reading the text. Word repetition will also make the reader give special attention to the word. Besides, it can be concluded that word with high repetition will be more easily remembered by the reader; indirectly the reader is acquiring the word.

Moreover, based on the result of this study, the application of narrow reading in acquiring vocabulary provides some advantages. First, narrow reading helps the reader to acquire a new vocabulary that is presented in the text. Second, reader will be easily comprehend the issue or the topic of the text, since the reader would meet some of the same vocabulary or term concerning with the issue or the topic of the text.

Regarding to the result of the study, narrow reading is not the only one factor that affect the students' vocabulary acquisition, but also the students reading ability have significant affect in acquiring the vocabulary. However, there is a strong link between vocabulary knowledge and reading comprehension. As it is stated by Matsuoka \& Hirsh (2010, p. 56) that in second language learning, which is the focus of this study, revealed high correlations between vocabulary knowledge and paragraph comprehension, an increase in L2 reading proficiency can be attributed to increased proficiency in vocabulary. As we know there are some aspects that may affect a person's ability to read, such as reading strategy, reading habits, reading speed, etc.

Therefore, if reading habit, reading strategies and reading speed followed by the selection of appropriate reading text such as the narrow reading, the vocabulary acquisition; which has been considered difficult by some people; will be easier to attain.

\section{Conclusion}

Based on the research findings, it can be concluded that there is a significant difference between score of experiment and control class in vocabulary test (posttest) after exposed to narrow reading. However, the statistical computation also shows that students reading score are also affected the students' vocabulary acquisition.

This study suggests, teachers are demanded to know not only how to teach reading but also pay attention in selecting the reading text for the students. In order the students not only learn how to comprehend the text but also to acquire vocabulary at the same time. However, vocabulary is one of important aspect in reading and one of way to acquire/ learn or to teach vocabulary is through reading, including narrow reading. 
Although the findings of this study have convincingly proven that narrow reading can help the students to acquire vocabulary, other further research of such this study is needed to be done. This experimental study was conducted for university students. It is not yet known whether an experiment conducted in lower levels also yields the same result. Moreover the topic for narrow reading that is given to the students is selected by the researcher; it is not selected by the students as their preference. Besides, the target words that are tested in this study limited, it is hoped that the future study will serve a large number of target words. Thus, this case is still needed careful examination in future research.

Most importantly, this study is only concern with the effect of narrow reading on student's vocabulary acquisition with the reading ability as the covariate. It is not yet included other variables that may have impact in vocabulary acquisition through reading, such as reading strategy, reading habit or the speed of reading. Therefore, it is suggested for the future research to include those variables in the study. Finally, it is hoped other study concerning with the application of narrow reading to develop the students' English language proficiency will be conducted.

\section{References}

Ary, Donald, Jacobs, Lucy Cheser and Razavieh, Asghar. (2002). Introduction to Research in Education (sixth edition). Stamford: Wadsworth Thompson Learning.

Brown, H. Douglas. (2007). Principle of Language Learning and Teaching (fifth edition). New York: Pearson Longman

Criado, Raquel. (2009). The Distribution of the Lexical Component in ELT Course Books and Its Suitability for Vocabulary Acquisition from Cognitive Perspective: A Case Study. International of English studies, special issue.

Gardner, Dee. (2008). Vocabulary Recycling in
Children's Authentic Reading Materials: A Corpus-Based Investigation of Narrow Reading. Reading in a Foreign Language. 20(1), pp. 92-122.

Hatch \&Brown. (1995). Vocabulary, Semantics, And Language Education. New York. Cambridge University Press.

Han, Zhaohong\& Alice, Cheng-ling. (2010). Repeated-reading-based strategy and vocabulary acquisition: a case study of a heritage speaker of Chinese. Reading in a foreign language. Volume 22. No 2. Pp. 242-262.

Heaton, J. B. (1988). (New Edition). Writing English Language Test. Harlow: Longman.

Hornby, A.S. 2000. Oxford Advanced Learner's Dictionary (new edition). Oxford: OxfordUniversity Press

Johnson, Keith. (2001). An Introduction to Foreign language Learning and Teaching. England: Pearson Education Limited.

Krashen. D, Stephan (2004). The case for narrow reading. Language Magazine 3(5) p:17-19

Krashen, D, Stephan (2009). Principle and Practice in Second Language Learning. University of Southern California. First internet edition.

Matsuoka, W \& Hirsh, D. (2010).Vocabulary learning through reading: Does an ELT course book provide good opportunities? Reading in a Foreign Language. Volume 22, No.1 pp. 56-70.

Nation, I. S. P. (2003).Teaching and learning vocabulary. New Zealand: English Language Institute.

Nation, I. S. P. (2001). Learning Vocabulary in Another language. Cambridge: Cambridge University Press.

Pigada, M. \& Schmitt. (2006). Vocabulary Acquisition from Extensive Reading: A case study. Reading in Foreign Language. Volume 18, p 1-28. 
Richards, J., \& Schmidt, R. (2002). Longman dictionary of language teaching and applied linguistics. Malaysia: Pearson Education.

Schmitt, Norbert. \& Carter, Ronald. (2000). The Lexical Advantages of Narrow Reading for Second Language Learners. TESOL Journal. P 4-9

Schmitt, Norbert. (2000). Vocabulary in Language Teaching. Cambridge: Cambridge University Press.

Schmitt, Norber. (2005). Current Perspectives on Vocabulary Teaching and Learning. TESOL Journal

TE: http://www.teachingenglish.org.uk/articles

Wijaya, Tony. (2009). Analisis Data Penelitian Menggunakan SPSS. Yogyakarta: Universitas Atma Jaya Yogyakarta.

Zhao, Lu. (2007). Narrow Reading and EFL Reading Teaching. Anshan Normal University,Anshan Liaoning. 